\title{
A Life Space Perspective to Approach Individual Demographic Processes
}

\author{
Éva Lelièvre \\ Institut National d'Etudes Démographiques \\ 133 boulevard Davout \\ 75033 Paris, France
}

\section{Nicolas Robette}

Università Bocconi

Vi Guglielmo Rontgen 1

20136 Milano, Italy

E-mail: nicolas.robette@unibocconi.it

\begin{abstract}
The concept of life space refers to the different locations with which individuals interact along their life course. In this article we present several methodological proposals to describe and measure various territories to which individuals relate over time, taking advantage of a rich data source, the Biographies et entourage survey. We produce relevant indicators which can be used in the study of different demographic processes and demonstrate how this perspective elegantly formalizes the linked dynamics of interactive non-independent trajectories in the case of the couples' activity space.
\end{abstract}

Key Words: Life-space, migration, trajectory, family network 


\section{Résumé}

Le concept d'espace de vie désigne l'ensemble des lieux avec lesquels un individu est en relation au cours de sa vie. Dans cet article, plusieurs méthodes sont proposées pour décrire et mesurer les différents territoires auxquels les individus sont attachés au fil du temps, en mettant pour cela à profit la richesse des données de l'enquête Biographies et entourage. Plusieurs indicateurs sont construits, qui peuvent être utilisés pour l'étude de processus démographiques variés. La pertinence d'une perspective en termes d'espace de vie est enfin validée par l'analyse des interactions dynamiques entre trajectoires nonindépendantes, appliquée aux espaces d'activité des couples.

Mots-clés: Espace de vie, mobilité spatiale, trajectoire, réseau familial

\section{Introduction}

It is an undisputed fact that individuals interact with a large number of different locations throughout their life, through their activities or their social network, and that their knowledge of and acquaintance with these places shape their behaviour. The study of species territory size, shape, etc. and its influence on mating, breeding and migration (see for example Brooker and Rowley 1995; Adams 1998; Tyre et al. 2001) represents a fecund stream in animal ecology. In social sciences, the largest body of quantitative research on this topic mainly concerns daily activity spaces, with studies related to time-use, transport planning, mental maps, environment and behavioural studies (with studies like Vilhelmson 1999; Hannes et al. 2008). They specifically refer to everyday mobility and perception (di Méo 1996), and is usually embedded in urban development and planning studies (Lefebvre 1991, 1974). When allowing for a longer time span and a wider territory made up of places visited but also known and important for social interactions, a conceptual framework exists which

CSP 2010, 37.1-2: 207-244 
refers to life spaces. Concerning peoples' behaviour, the fact that these territories constitute a meaningful subject of research can be traced back, in France, to a first stream which emerged among geographers in the early 1970's (Chevalier 1974; Frémont 1974; Metton 1974) and which appears in demography with the work of Courgeau $(1975,1988)$. The references to life spaces in demography mainly pertain to migration studies. Fewer mentions are made in English (Hugo 1982; Ley 1983; Hooimeijer and Van der Knaap 1994), though a number of modelling procedures of migration with reference to known territories can be found (Brown et al. 1970; Gordon and Vickerman 1982). The relative scarcity of studies is not due to the lack of conceptual framework but rather to the lack of available quantitative data. The description and modelling of life spaces and furthermore the practical use of relevant measurement in demographic studies has yet to be developed.

The objective of our paper is to present a set of possible methods to describe these territories and advocate the potential use of such an angle for the study of demographic processes. Taking advantage of a rich data source, the Biographies et entourage survey conducted by INED in 2001, and the abundant existing conceptual framework, we proceed here gradually, introducing alternative strategies for the quantitative measurement of different types of life spaces. We deal first with static territories, such as the territory of origin, the childhood reference space, the life space at one point in time. We then proceed to modeling the dynamics of the activity space of a couple defined by the territory covered by their place(s) of residence and place(s) of work since the beginning of their union.

\section{The Life Space and Theoretical Propositions}

A life space perspective, understood as an approach relating individuals to the set of locations with which they interact, is a useful proposal for studying several aspects of population behaviour. Among social science researchers, especially geographers and demographers, the notion of life space was initially developed with the aim of better understanding spatial mobility and expanding the study of migration. Our understanding of migration, usually considered as a simple change of residence, would indeed be extended if the acknowledgment that individuals interact with a large number of different locations could somehow be taken into account. This could include various types of migrations, from intra-urban resettlement to transnationalism practices. Nevertheless other demographic behaviours such as union formation, intergenerational relationships or fertility could also benefit from a 'social space' perspective that details the constraints and opportunities available locally. For instance, life spaces would make an interesting framework to analyse the structural dimension of

CSP 2010, 37.1-2: 207-244 
intergenerational solidarity, which considers the number, type and geographic proximity between family members (Bengtson and Roberts, 1991).

Coming down to available definitions, the concept of life space covers a wide range of possible meanings. We deal with a territory "constructed with all the places with which individuals are interacting simultaneously, directly or through the people who live there". It covers "the portion of space where individuals conduct their activities. This notion includes not only passing and staying places, but also every other place with which the individuals are in contact" (Courgeau 1988).

These include the social space - the set of locations defined by social relationships: places of residence of family members and friends, for example the awareness space - the territory with which people identify and which is not only based on experiences such as birth place of ancestors, relevant religious locations, etc. - the activity space which refers to the territory where people conduct their activities (Hooimeijer and Van der Knaap 1994). But according to the studies and the data available, these territories can differ wildly and cover quite different concepts: for example awareness space may be defined as the set of locations about which the individuals possess some knowledge and which intervene in modelling the migrants' choice of destination (Brown et al. 1970). These territories are also constructed with reference to different time scales, from the everyday life space where individuals conduct their daily activities to the life spaces of the life course regrouping all the residential locations of an individual from childhood to retirement (Bonvalet et al. 2009). The activity space can encompass all daily activities (shopping, working, leisure activities and so on...) or be precisely defined as a set of locations with which individuals have direct contact as opposed to the awareness space.

Theoretical definitions abound, but empirical research is more scarce. Quantitative information about the territories of individuals is hard to obtain. As mentioned before, time-use studies and transport surveys cover the daily activity space and are often associated with psychology and behavioural studies. Qualitative, mainly monographic, approaches are also found, concerning specific populations, especially in ethno-anthropological research and in geography (Kokoreff 1994; Collignon 1996; Avenel 2000).

\section{The Data}

The quantitative description of life spaces often comes up against a data problem. Indeed, in a practical sense, it seems unworkable to record all the various places taken into account by the extensive definition of life spaces, not only because of the cost it would incur, but also because of the respondents' memory limits. But these definitions provide a sound theoretical framework for the more practical territories that empirical work can construct and analyze.

CSP 2010, 37.1-2: 207-244 
A Life Space Perspective to Approach Individual Demographic Processes

The Biographies et entourage survey conducted by INED in 2001, collected 2,830 life histories of individuals' contact circles (entourage). Family, residential and occupational event histories along four generations were recorded through interviews with people born between 1930 and 1950 and living in the Paris region (Lelièvre and Vivier 2001). For our study, this unique life event history data set provides information on a large number of different places for the respondent and his/her family members all along the life course (Table 1), such as all places of residence and work, birth places, residences of the respondent's family members. It also includes a range of other varied locations: some visited - boarding school, holiday home, week-end residence, etc. - some evoked - important places, desired residential locations, future place of residence, etc.

This enables us to describe a large range of different life spaces using:

- Family locations such as the places of birth, the places

of residence of the respondent's parents, children, siblings and spouse's parents;

- Everyday life locations, such as the places of residence and the places of work of the respondent and her/his spouse;

- Chosen locations, i.e. second homes and other locations visited regularly.

In this way, we cover simplified but comprehensive territories combining various types of location which reveal a wide variety of the respondent's spatial practices. This allows us to explore different methodological approaches adapted to each type of identified life space.

\section{Life Spaces: Empirical Propositions}

Different types of life spaces can be defined for the purpose of measuring the portion of people's territory to which they relate or belong, with which they interact at particular moments or throughout their life. From among this choice of potential reference territories, we thus propose to explore four:

The territory of origin which describes "where we come from" comprising the six places of birth of the parents and grandparents; 
The childhood reference space where individuals spent their early social life: "where we grew up" comprising all the places of residence where the respondents lived before the age of 14 .

The life space at the time of the survey "constructed with all the places with which individuals are interacting simultaneously, directly or through the people who live there". This combines locations where people conduct daily activities (residence, work), which they visit (week-end, holiday residences) and places of residence of their parents, children and other family members.

Finally, the couple's activity space, comprising the places of residence and work of both members of a couple during their union, will here serve to explore the territory resulting from linked trajectories of partners. For that purpose, all places of residence and work of the respondents and their spouse are necessary from the beginning of their union (Massot 1998). This will allow us to study how this joint space evolves in time, with the arrival of children, the instability of work and the changes of residence.

The first two life spaces (territory of origin and childhood reference space) have been well identified and derive from qualitative sociological studies (Gotman 1999; Bonvalet et al. 2007). The life space at the time of the survey is an empirical example of the conceptual life space presented by Courgeau (1988), and the couple's activity space is a simplified parsimonious territory which allows a first approach to the dynamics of life spaces.

These four types of life space present different challenges for their description and statistical measurement (Lelièvre and Robette 2005). The territory of origin is a memory space which does not necessary involve visits. The childhood reference space comprises a succession of locations and opens the question of how to summarize a territory made up of locations and durations. The life spaces defined here at the time of the survey combine locations of different natures, where people have different activities and various ties. Finally, we will attempt to model the dynamics of the couple's activity space with the information provided by Biographies et entourage survey on the entire residential and occupational histories of the respondents and their partners: a territory which comprises a maximum of three locations and a minimum of one and evolves over the couple's shared life course.

We will successively examine the four territories which present increasing levels of complexity, illustrating our study with applications using the Biographies et entourage survey data.

CSP 2010, 37.1-2: 207-244 
Table 1

All Locations Collected in the Biographies et entourage Survey

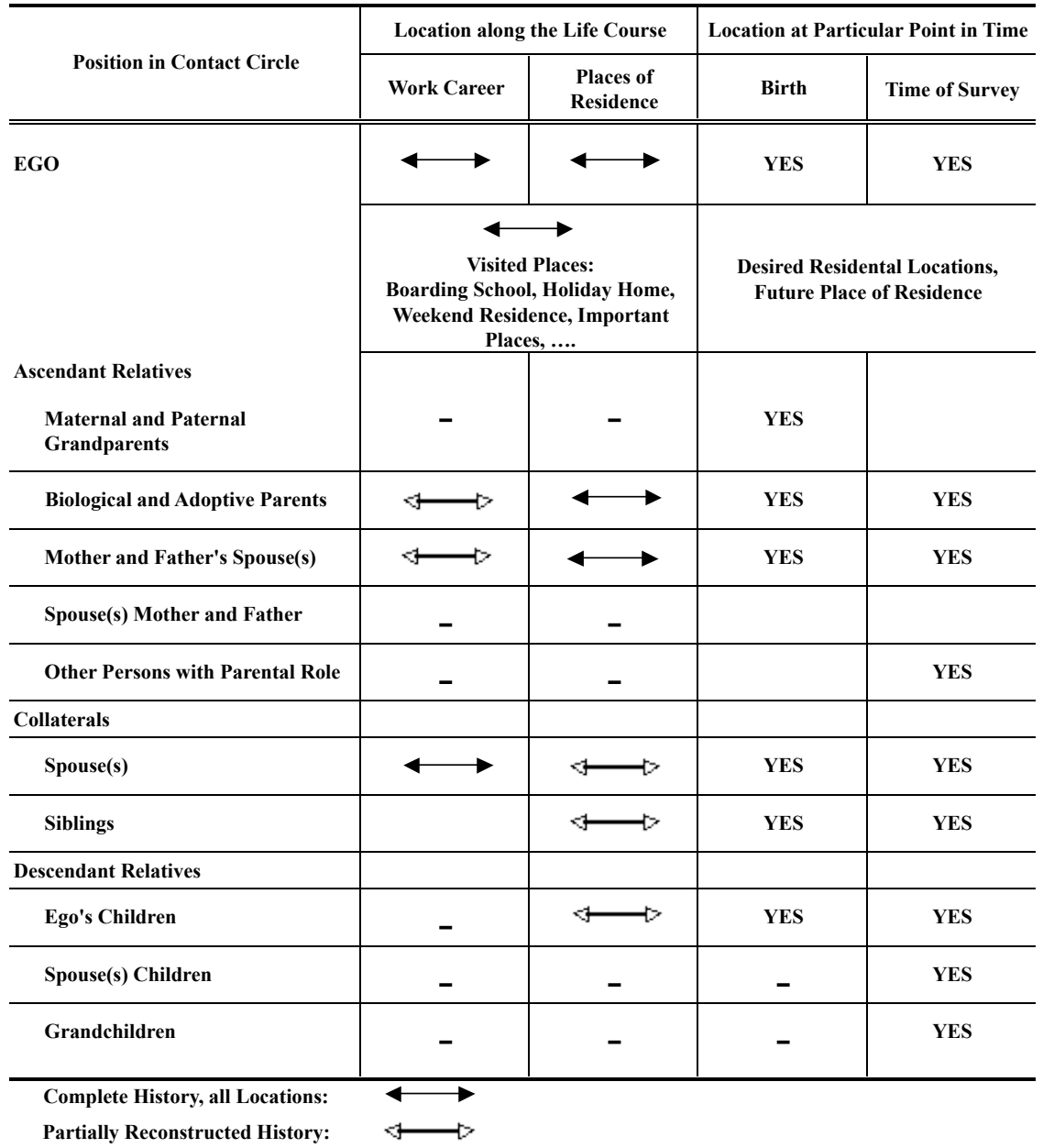




\section{The Territory of Origin}

We are dealing here with a sentimental territory which does not necessarily involve personal experience or physical visits: the place of origin, the place where we come from. But its role is important if not crucial for understanding people's migration strategies along the life course, especially at the time of retirement (Warnes 1993; Cribier 1999). It also represents decisive information to supplement individual characteristics in the study of family formation, the work career of immigrants and their children for example (Meurs et al. 2006).

Comprising the places of birth of parents and grand parents, its theoretical maximum size is six locations. Empirically, for data collected in a survey, two practical hurdles are encountered in terms of data availability: the difficulties certain individuals may have in naming those six places, and the variability in the geographical precision of the location given. In the Biographies et entourage survey, more than three-quarters of the respondents were able to give full information on the locations of their origin, with a geographical precision which ranges from the département ${ }^{1}$ to the region. For residents of the Paris region born from the $1930 \mathrm{~s}$ to the $1950 \mathrm{~s}$ (survey respondents), $48.5 \%$ of their territories of origin are confined to one region only. For a further $10 \%$ of respondents, their origins are grouped in a single region except for one location. A division along family branches appears for the others, with $14 \%$ of these territories divided spatially into a maternal versus paternal region. The Biographies et entourage survey respondents are characterized by their specific migration profile, as they "came to the capital" in massive numbers (only 39\% were born in the Paris region), a fact that explains the quite varied types of origin described here for these generations.

\section{The Childhood Reference Space}

The childhood reference space is a complex territory, a portion of residential trajectory comprising all the places of residence where the respondents have lived before the age of 14 years old ${ }^{2}$, whose influence on later mobility is strong and diverse (Courgeau 1985). The challenge is to combine the varying number of geographical locations with the time spent in each place and the number of moves (several residences can be located in the same municipality). Table 2 presents the combination of these three indicators expressed at the detailed geographical level of the municipality (commune). It shows a complex picture. The table distinguishes between individuals for whom a dominant location can be identified and the more mobile ones. Empirically for the Biographies et entourage survey respondents, an overwhelming $91 \%$ of respondents spent at least eight years (more than half their childhood to the age of 14) in the same municipality, irrespective of the fact that they may have changed dwelling 
within the same municipality. And more than half of the respondents $(52 \%)$ stayed in one municipality in the same residence for the whole period (Table 2).

\section{The Life Space at any Point in Time}

This third type of life space examined here derives from the idea of taking into account at a particular point in time - here at the time of the survey - the respondents' place of residence and place of work (in reference to the notion of activity space), plus the respondents' parents' place of residence, their children's and sibs' places of residence i.e. their network space (in reference to the notion of social place) and some components of the space with which people identify, i.e. holiday places and others important places quoted by the respondents in reference to the notion of awareness space).

To describe the individuals' life spaces and summarize their main characteristics, different dimensions may be considered.

Table 2

A Proposed Typology for Childhood Reference Spaces (from 0 to 14 years old)

\begin{tabular}{|c|c|c|c|}
\hline \multirow{2}{*}{$\begin{array}{l}\text { Number of Distinct Municipalities } \\
\text { When there is a dominant location }\end{array}$} & \multicolumn{3}{|c|}{$\begin{array}{c}\text { With Intra-Municipal Moves } \\
\text { (has changed dwelling within same } \\
\text { municipality) }\end{array}$} \\
\hline & No & Yes & Total \\
\hline $\begin{array}{c}\text { (i.e., at least } 8 \text { years in one of the } \\
\text { municipalities) }\end{array}$ & 55.7 & 34.9 & 90.6 \\
\hline Only one municipality & 33.8 & 18.5 & 52.3 \\
\hline Two municipalities & 16.5 & 11.7 & 28.2 \\
\hline Three or more municipalities & 5.4 & 4.7 & 10.1 \\
\hline $\begin{array}{l}\text { Multiple locations, with no } \\
\text { dominant one } \\
\text { (i.e., less than } 8 \text { years in each } \\
\text { municipality) }\end{array}$ & 5.2 & 4.2 & 9.4 \\
\hline Total & 60.9 & 39.1 & 100.0 \\
\hline
\end{tabular}

Source: Biographies et entourage survey, 2001.

CSP 2010, 37.1-2: 207-244 
The first dimension is the number of different locations ${ }^{3}$ which here, by design, are contingent upon the size of the respondents' contact circle (a Pearson coefficient between the two is always significant).

The second measures the composition of the life space. For the survey respondents, half of the locations of their life space at the time of the survey correspond to the residences of their siblings and children. Obviously, some kind of weighting should be introduced reflecting the visits to the different locations of the life space, an item of information available in the survey.

A third dimension is the polarization of the life space, taking the respondents' place of residence as its "centre". While the spatial distribution of all the locations indicates its territorial extent, the dispersion of the locations around the respondent's place of residence indicates its degree of centrality within the life space, bearing in mind that the territories between these locations are not necessarily known or visited. To measure this, the distances between all locations are needed. They are computed here from their geographical coordinates, but other measures such as the travelling distance between them could be a better proxy.

\section{A Method of Identification}

When represented on a map (Figure 1), the family space of respondents corresponding to the locations of the members of three different family networks (Lelièvre and Imbert 2002), delimits portions of the life spaces and gives us an insight into the different dimensions to be considered. On Figure 1, a circle is either traced when concentration is high and distance short or when there is only one location but a distant one. This suggests that we must combine distance and concentration criteria to define hubs, though distance nonetheless prevails.

Consequently, we empirically identify clusters of location on the basis of their proximity and choose meaningful criteria to qualify the clusters obtained as hubs or simple extensions of the life space for the single distant locations. The criteria can be crude (a hub must group more than $n$ locations, for example) or more refined, depending on the information available and the objective of the study: for instance, the distance to the individual's residence can be combined with the nature of the locations grouped in the clusters, etc. To identify the structure of life spaces, we then proceed by steps:

1. Using a Hierarchical Cluster Analysis on the spatial coordinates of all locations of each respondent's current life space, we first proceed to identify clusters made up of locations according to their relative distance, normalized with respect to the total dispersion of each life space. Applied to the whole sample of the Biographies et entourage survey, the cluster analysis of individuals life spaces at the time of the survey is performed and then a partition

CSP 2010, 37.1-2: 207-244 
is set at a threshold of $98 \%$ of explained heterogeneity. It produces small clusters: nearly two thirds (63\%) of them contain only one or two locations. The number of clusters per individual life space is also limited: $67 \%$ have fewer than four clusters. We must proceed to further groupings.

2. The second step aggregates clusters or isolated locations if the distance to the respondent's residence is below a chosen threshold. This threshold must take into account the specificity of the sample. Here all clusters/ locations situated less than $50 \mathrm{~km}$ from the respondent's place of residence are grouped, characterizing the average distance between the centre of Paris and its outermost suburbs.

3. Finally, in order to identify hubs among the clusters obtained, a relevant criterion must be chosen. The selection criterion can either be the concentration of locations, the composition of the cluster, the frequency of visits, etc. depending on the data available and the research question. In our case, we chose a concentration criterion of a minimum of three locations needed to define a hub.

We will illustrate this process with an example. Guillaume's life space (Figure 2) is made up of 10 locations which the Hierarchical Cluster Analysis (step 1) consolidates into three clusters (dotted contour lines) grouping respectively:

- Guillaume's residence and work place and his son's place of residence in the Paris region,

- both his parents' places of residence (they live separately), also in the Paris region,

- his three sisters' different places of residence in the south-west of France,

- and two isolated extensions of Guillaume's life space

- his daughter's place of residence in Angers,

- his brother's place of residence in Normandy.

Then (step 2), all places in a radius of less than $50 \mathrm{~km}$ from Guillaume's place of residence are aggregated to its cluster. There are then two clusters left. Finally (step 3 ), only the clusters containing at least 3 different locations are 
Figure 1

Three Territorial Locations of Respondents' entourage

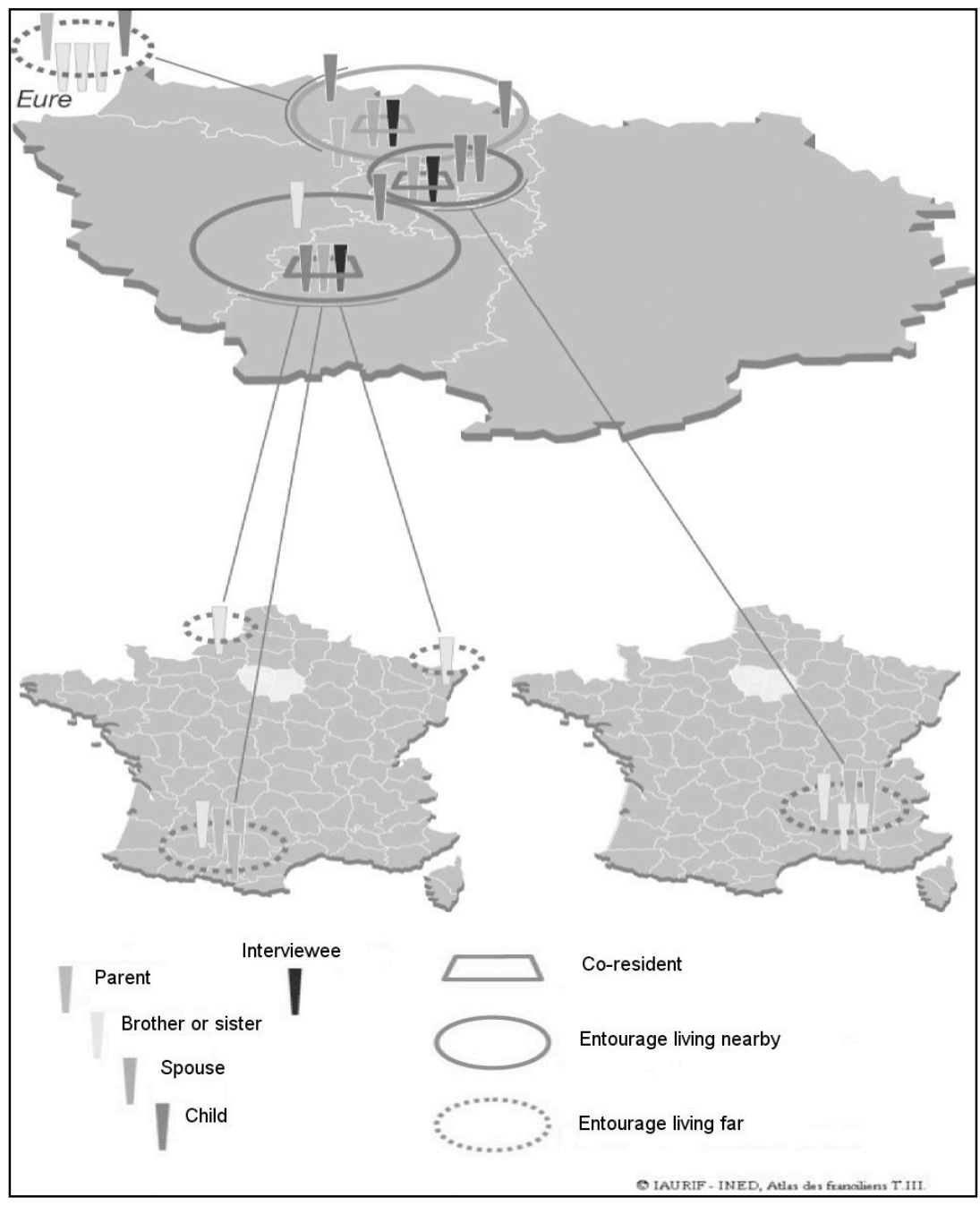

Source: Biographies et entourage survey 
qualified as hubs: Guillaume's life space is made of 2 distant hubs (continuous lines) and 2 residual locations.

The distribution of life spaces, obtained from the whole sample, characterized by the number of their hubs is presented in Table 3. Only one-fifth of life spaces comprise more than two hubs. For the total sample $(2,830$ respondents, hence life spaces), with the additional distinction that the respondent's place of residence belongs in a hub or not, we get the following typology:

- $55 \%$ have a life space with one hub where they reside,

- $21 \%$ have a life space with multiple hubs (and mostly reside in one of them),

- $15 \%$ of respondents have a life space without hubs,

- $9 \%$ have a life space with one hub where they don't reside.

This resulting typology is shaped by the family network size and the different propensity of each type of location to be grouped. The respondents' place of work and the places of residence of their children have more than onein-two chance of being in the hub where the respondent lives, while second homes and other visited places have a similar chance of standing as a residual location. In that sense, the life space perspective reveals the interplay of family organization.

Table 3

Distribution of Current Life Space of Individuals by Number of Hubs

\begin{tabular}{ccc}
\hline Hubs per Life Space & Percentage & Cumulated Percentage \\
\hline $\mathbf{0}$ & 14.6 & \\
$\mathbf{1}$ & 64.0 & 14.6 \\
$\mathbf{2}$ & 20.1 & 78.6 \\
$\mathbf{3}$ or more & 1.3 & 100.7 \\
& & \\
\hline
\end{tabular}

Source: Biographies et entourage survey, 2001. 
Figure 2

The Locations, Clusters and Hubs in Guillaume's Life Space

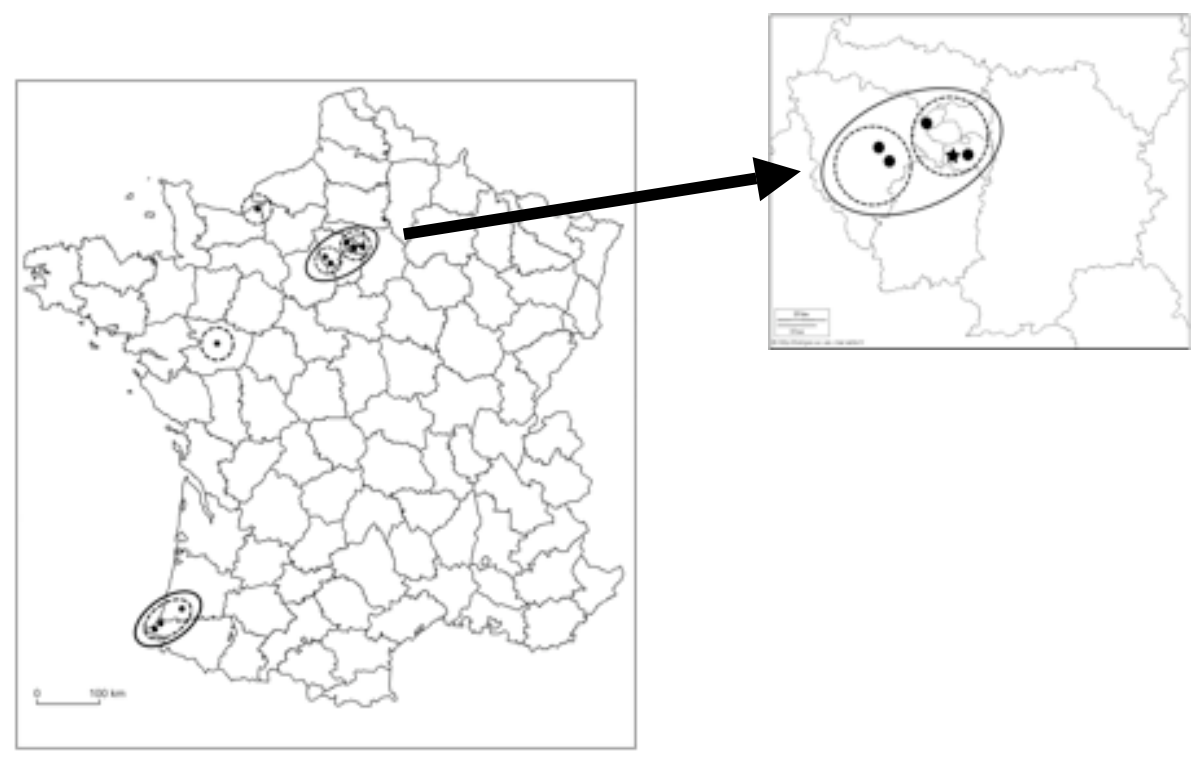

(An example from Biographies et entourage)

Guillaume lives in a close suburb of Paris (Val-de-Marne), as does his son. He works in another subuParis region.rb (Hauts-de-Seine) - all these locations are situated in the Paris region. His daughter lives in Angers (Maine-et-Loire), his brother in Honfleur (Normandy), his parents (separated) in Plaisir (Yveslines) and his three sisters in Saint-Jean-de-Luz, Biarritz (Pyrénées Atlantiques) and Dax (Landes) in the south-west of France. 


\section{Life Space: a Social Space of Intergenerational Relationships}

Demographers and sociologists have also approached families as configurations structured by the relationships between their members. This configurational approach is sometimes presented as a development of relational sociology and a means to go beyond the restrictive concept of the nuclear family (Widmer and Jallinoja 2008). And sometimes individual networks are characterized by the manner in which their members construct different 'environments of kin' within the boundaries of space (Wellman 1999). The idea that the household is too restrictive to capture social interactions which develop beyond the circle of kin and outside coresidence constitutes another approach to networks which are anchored in their spatial context (Bonvalet and Lelièvre 1995; Lelièvre et al. 1998). A large body of demographic studies based on quantitative surveys exploring the exchanges between family members now exists in many European countries (see Bonvalet and Ogg 2007, for a comparative review). The Biographies et entourage survey, used here, was designed to describe the entourage of individuals extended to family members outside the household whose locations are recorded. In fact, it appears necessary to look beyond the household to study contemporary trends in family life and to take into account the strong ties that are formed beyond marriage and consanguinity. The notion of localized relationships through their proximity and frequency was developed to qualify the support network of individuals (Bonvalet and Lelièvre 2007; 2008). And the presence of the famille-entourage lifestyle anchored on a territory bears witness to a reality, in quantitative terms at least. The notion of individual life space is therefore attained via the 'environment' comprising the residences of entourage members and proves very relevant to understand the making of intergenerational relationships and their developments over time.

\section{Life Space between Past and Future}

Life space has been examined at a precise moment, the time of the survey. But it is also a component of a history, which evolves along the life course: it is a dynamic entity. This link between space and time can be highlighted by comparing the current life space with locations tied to other periods of the life course, past or future.

If we explore the link between the current life space and a reference space of the past, i.e. the territory of family origins, defined by the birth places of the parents and grand-parents, it appears that more than fifty per cent of current life spaces described in Biographies et entourage encompass at least one birth place of an ascendant, whatever their structure. This confirms the strong tie between past and present, even though we are dealing with a specific sample drawn from the Paris region and where six out of ten respondents were themselves born

CSP 2010, 37.1-2: 207-244 
outside the region. This place of origin belongs preferentially in a hub and, considering that $58 \%$ of the territories of family origins are grouped in the same region (section 3.1.), it shows its strength as the respondents' reference space.

If we now explore the influence of the current life space on future residential moves by examining the respondents' intentions to move and the anticipated place of destination, those who intend to move $(36 \%$ of the respondents) are not randomly distributed across the life space configuration (Table 4). Indeed, only $19 \%$ of the respondents with unstructured current life space intend to move, whereas the proportion is $31 \%$ among those who live offcentered. A closer look shows that the number of hubs in the life space is not discriminating in the intention to move. Comparing desired destinations and the locations of current life-space hubs, we observe that $36 \%$ of those whose residence is off-centered and who intend to move quote a destination located within the hub, suggesting that hubs are a potential destination.

The structuring of current life space locations into hubs and webs of places, constitutes a new tool to be perfected. It enables us to introduce the description of life spaces, summarizing their size, composition, location, in a simplified but nonetheless precise manner. It is relevant to the study of family networks and sheds new light on spatial proximities. Usually considered as the context in which network functions, the life space structures in terms of hubs and distant locations can in turn inform about the potential relationships and interconnexions within the networks described. Rapid exploration confirms also that the current life space determined by past inherited locations is also a determinant of future mobility, and consequently of the future life space.

Table 4

Intended Destination of the Next Move and Current Life Space of Individuals

\begin{tabular}{ccc}
\hline Type of Life Space & \multicolumn{2}{l}{ Intend to Move (\%) } \\
\hline $\begin{array}{c}\text { With one hub containing respondent's } \\
\text { place of residence }\end{array}$ & Yes & Probably \\
With multiple hubs & 22.5 & 14.1 \\
$\quad$ Without hubs & 25.8 & 15.7 \\
$\begin{array}{c}\text { With one hub which does not contain } \\
\text { respondent's residence }\end{array}$ & 19.1 & 14.1 \\
& 31.2 & 16.2 \\
\hline
\end{tabular}

Source: Biographies et entourage survey, 2001.

CSP 2010, 37.1-2: 207-244 


\section{The Couple's Activity Space}

As yet, we have envisaged individual life spaces, but most demographic processes originate and result from several people joint decisions, something which proves difficult to model (see work on marriage market for example: Ní Bhrolcháin and Sigle-Rushton 2005). Therefore we now apply the life space approach to linked individuals i.e. couples. The couple's activity space refers to 'the radius within which the two members of a couple conduct their activities'. It is approached here through a maximum of three locations corresponding to their place of residence and place(s) of work (Clark and Kuijpers-Linde 1996).

At the time of the survey, $78 \%$ of the respondents aged 50-70 lived in a couple, so there is information in the data set for 2,222 couples. These couples have different occupational profiles: in $29 \%$ of them both partners are inactive, while in $37 \%$ both are working. The remaining ones, not surprisingly, count more couples where the male partner works and not his spouse $(20.5 \%)$ than the reverse $(13.5 \%)$.

The territories covered by the activity spaces of the surveyed couples are of various sizes, depending on the number of locations and the distances between them. When only one partner works (a third of the couples at the time of the survey), whatever the distance indicator, women consistently work closer to home (Table 5). In the case of bi-active couples (37\% of respondents) Table 6 describes the distribution of the three locations, and whether the residence and work places are situated in the same département or even in the same municipality.

As observed before, $20 \%$ of the activity spaces are confined to the same municipality (commune), while 14\% extend over three départements. Distances vary greatly from one extreme to the other. When the activity space covers two locations (39\% of dual-earners' activity spaces extend over two communes), in more than half (54\%) of the cases it is the couple's home and the woman's place of work which are the closest (Camstra 1996; Genay 1992).

\section{Changes in the Couple's Activity Space}

From the beginning of the union to the time of the survey, a couple's activity space evolves. Distances from home to work change over time, the number of locations in the activity space changes over time, the duration in each configuration varies, the characteristics of the couple (occupation, children, etc....) also. All these dimensions can be modelled, typologies established and analyzed. 
Table 5

Distances between the Residence and Work Places of Couple Members at the Time of the Survey when only one of them Works

\begin{tabular}{lcccc}
\hline $\begin{array}{c}\text { Gender at } \\
\text { Work }\end{array}$ & $\begin{array}{c}\text { Same } \\
\text { départment }\end{array}$ & $\begin{array}{c}\text { Same } \\
\text { commune }\end{array}$ & $\begin{array}{c}\text { Median } \\
\text { distance }\end{array}$ & $\begin{array}{c}\text { Mean } \\
\text { distance }\end{array}$ \\
\hline & $\mathbf{( \% )}$ & $\mathbf{( \% )}$ & $\mathbf{( k m )}$ & $\mathbf{( k m )}$ \\
Man Works & 45.6 & 14.5 & 9.4 & 65.2 \\
Woman Works & 60.4 & 25.6 & 4.9 & 46.2 \\
\hline
\end{tabular}

Source: Biographies et entourage survey, 2001.

Population is respondents living as a couple at the time of the survey, $n=2,222$.

Still considering the sample comprising couples at the time of the survey and looking back to the beginning of their union, a majority of the respondents belonged to working couples, 7 out of 10 were both working and in only 2 out of 10 the man was the sole earner (Table 7). Their mean union duration is 31 years, with a wide range. At the time of the survey, aged between 50 and 70 years old, some of the respondents and/or their partners are now retired which translates into more couples where both partners are inactive and, due to the age difference, more where only the woman still works.

These changes reflect the occurrence of transitions along the union life course. Several types of transition can be identified, taking into account the changes in any of the three locations (place of residence, respondent's place of work, his/her partner's place of work). The place of residence may or may not change (the couple move house), but it is a pivotal location in the sense that the cohabiting couple always have a place of residence ${ }^{4}$. Considering both partners work places along the union life course allows more transitions to take place. They depend on the initial situation: if the man (respectively the woman) is working, his/her place of work can change location or disappear (if they quit working); alternatively they may start working. A transition occurs whenever there is a change in one of the locations between time $t$ and $t+1$. Table 8 summarizes the most frequent transitions observed for the 2,222 respondents, aged 50 to 70 years old, living in a couple at the time of the survey. Although 5 types of transitions reflect more than half of all observed transitions and 9 types capture more than three quarters, the range is nevertheless broad. The mean number of transitions during the union is 2.55 with a corresponding 3.55 mean number of situations, i.e. each couple in the sample has experienced more than 


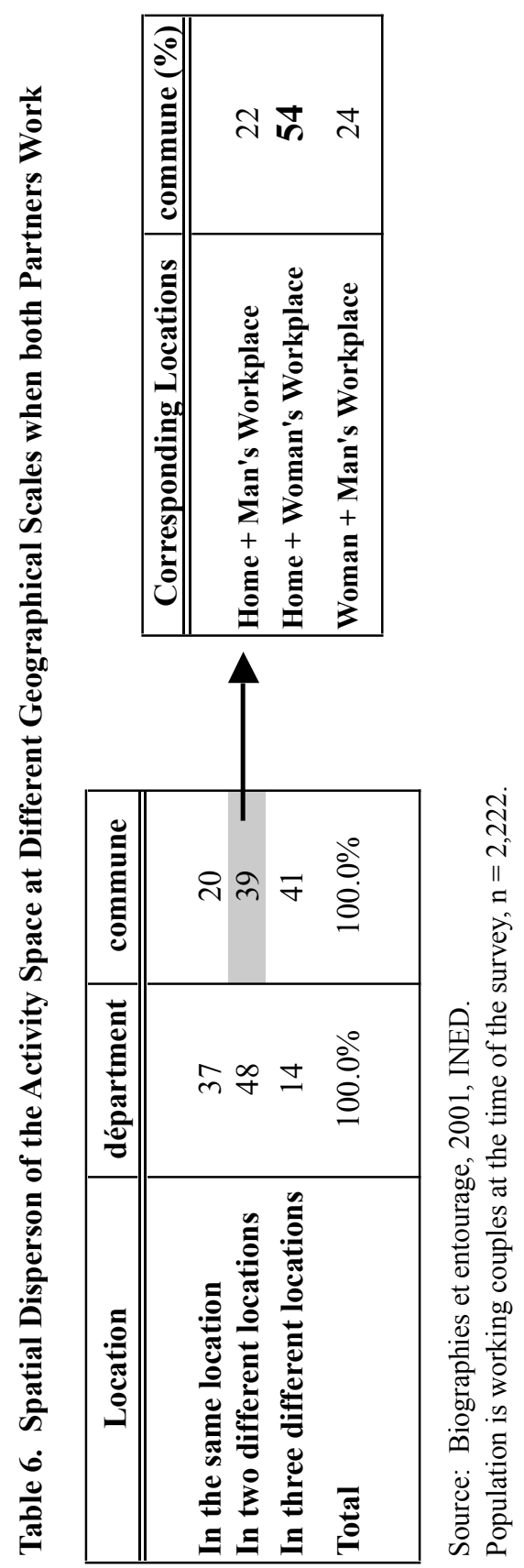


three different configurations of their activity space during their union (whose mean duration is 31 years).

To describe the territories covered by the activity spaces, we need to introduce a distance indicator to characterize the different situations. To do so, we cross-match the activity or inactivity of each spouse and a proximity index indicating whether the different locations are in the same commune or not. Ten different situations are then identified (Table 9). When both partners of the couple work, their activity life space can be spread over two or three different locations or concentrated in the same commune. Reciprocally, if geographically extended activity spaces covering three locations can only correspond to a dualearner couple, an activity space spread over two locations covers a wide range of situations.

Table 7

Couples' Activity Status over Time

\begin{tabular}{ccc}
\hline Work Activity & $\begin{array}{c}\text { At the beginning } \\
\text { of the union }\end{array}$ & $\begin{array}{c}\text { At the time of the } \\
\text { survey }\end{array}$ \\
\hline Both partners inactive & 1.5 & 10.5 \\
Man working & 21.3 & 32.4 \\
Woman working & 6.5 & 18.3 \\
Both partners working & 70.7 & 38.8 \\
Total & 100.0 & 100.0 \\
\hline
\end{tabular}

Source: Biographies et entourage survey, 2001.

Population is respondents living as a couple at the time of the survey, $\mathrm{n}=2,222$.

\section{A Typology of Couples' Activity Spaces}

Having identified the different transitions and the variety of activity space configurations, the use of a holistic approach seems appropriate to describe the whole history of couples' activity spaces over time, taking trajectories "as a whole" (Billari 2001). 


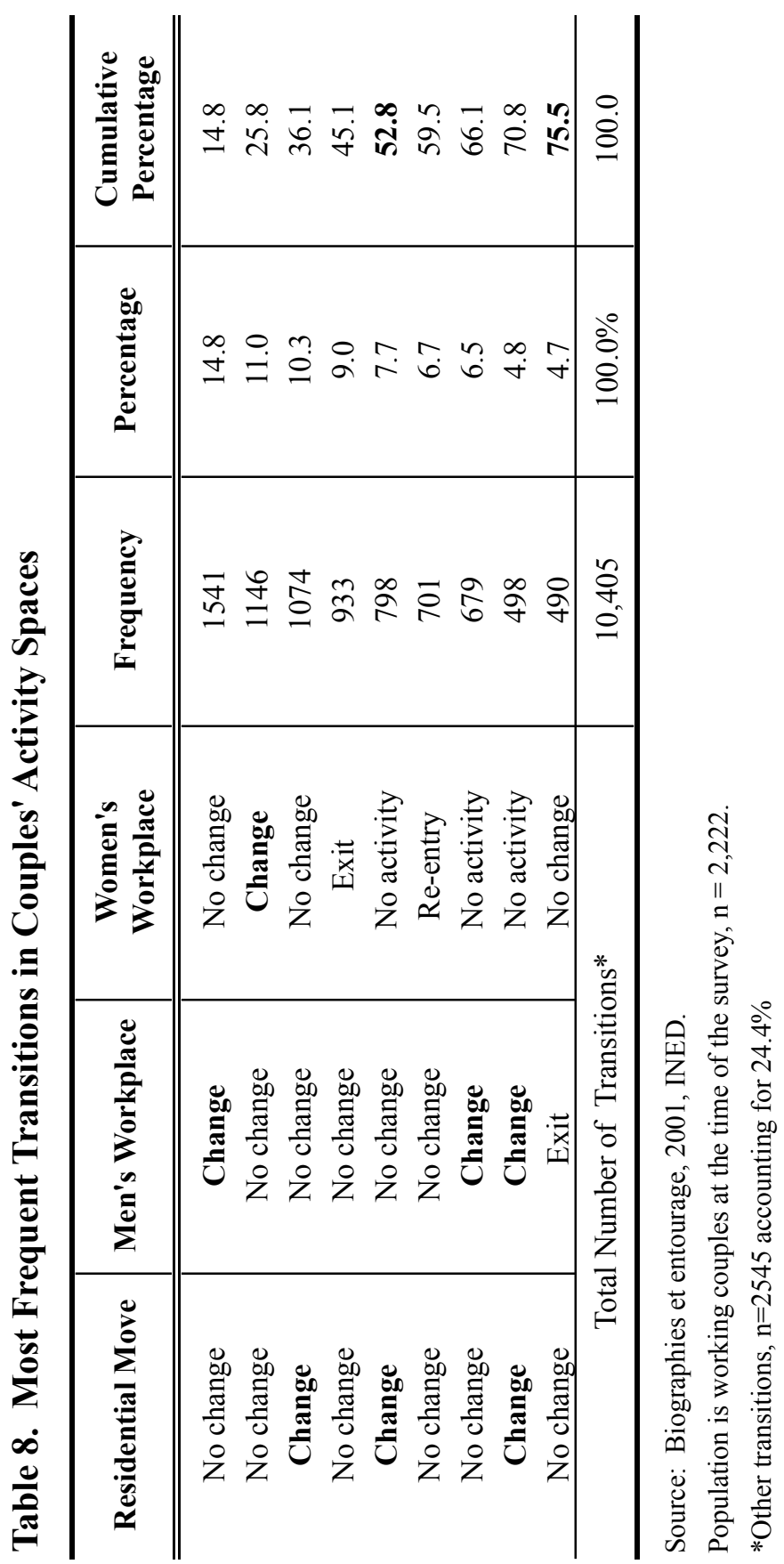

CSP 2010, 37.1-2 207-244

227 


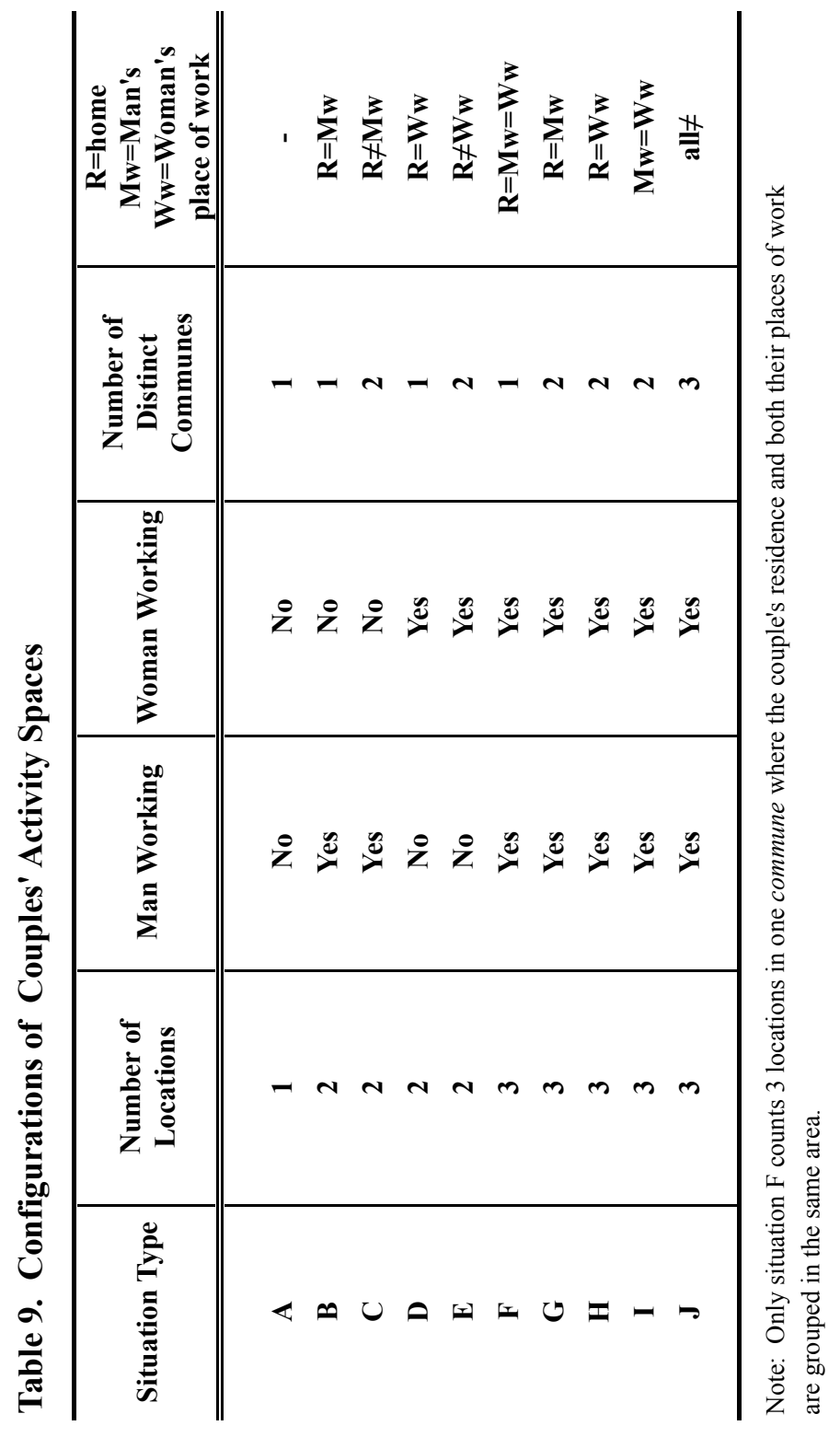

CSP 2010, 37.1-2: 207-244

228 
Several holistic methods are available. The most common one, Optimal Matching Analysis (OMA), consists in representing the trajectories as sequences and computing divergences between these sequences (Abbott 1995). It has often been used in the study of occupational or 'class careers' (Abbott and Hrycak 1990; Halpin and Chan 1998; Blair-Loy 1999), but also of housing careers or residential trajectories (Clark et al. 2003; Stovel and Bolan, 2004). However, the couples' histories in our sample have the distinctive feature of widely varying durations: from less than a year to 53 years with a median value of 31 years. And yet while OMA can theoretically deal with trajectories of variable lengths, its use with such heterogeneous durations is relatively complex to implement (Stovel et al. 1996) and has seldom been tested.

That's why we chose to use an alternative method, Qualitative Harmonic Analysis (QHA), linked to the tradition of French Data Analysis, upon which we already relied to describe the life spaces at the time of the survey. QHA was developed at the beginning of the 1980's (Deville and Saporta 1980) and then applied in the 1990's (Degenne et al. 1995; Barbary and Pinzon Sarmiento 1998). The analysis principle consists in splitting the trajectory into periods and, for each individual, measuring the proportion of time spent in each situation per period. The matrix thus computed is then submitted to a Correspondence Factor Analysis and a clustering method is used to build a typology of trajectories (Robette and Thibault 2008). In the common use of QHA, period duration is measured by the number of months or years. But it can easily be adapted to trajectories of varying length, by splitting the trajectories into periods representing a given proportion of the total duration ${ }^{5}$.

Having identified ten configurations of the activity space (Table 9), we chose to concentrate on couples living together for at least 5 years, as a shorter duration would not be very revealing in terms of changes in the couple's activity space. The resulting sample finally includes 2,108 couples. The couples' activity space trajectories are here split into 5 periods of equal length. For each of these 5 periods, the proportion of the period duration spent in any of the identified configurations is computed for each couple: the matrix size is $5 \times 10=50$ elements ( 5 columns and 10 lines corresponding to the configurations described in Table 9). For example, a couple in which both spouses work in their commune of residence (situation $\mathrm{F}$ ) for 10 years and then the woman becomes inactive (transition $\mathrm{n}^{\circ} 4$ in Table 8 to situation B) for another 10 years will contribute to the matrix by the following values: 1 in F1, 1 in F2, 0.5 in F3 and B3, 1 in B4, 1 in B5 and 0 in every other position. In this example, the trajectory lasts 20 years and is divided into 5 periods of 4 years each.

These matrix elements are submitted to a Correspondence Factor Analysis, then a Hierarchical Cluster Analysis is applied to obtain a typology. Six clusters are presented in Table 10. They were determined so that each cluster grouped at least a hundred trajectories. The classification procedure seems to

CSP 2010, 37.1-2: 207-244 
group likely trajectories mainly on the basis of the duration spent in one situation: here each of the clusters is characterized by a situation which lasted on average between 59\% and 74\% (Appendix A) of the total duration of the union. This situation appears in Table 10 labelled as 'mainly'. It is also possible to visualize changes in the different situations with union duration for each profile. The graphs (presented in Appendix B) show at each period the distribution of the situations in the cluster, the 'main' situation appearing dominant.

The main cluster (cluster 1 which represents $40 \%$ of the couples) contains bi-active couples with an activity space composed of three distinct locations. The high level of heterogeneity is chiefly due to the retirement of one of the spouses before the end of the trajectory. Nonetheless, these trajectories are the most stable ones: the average number of situation changes (2.23) is the smallest in this cluster (Appendix A). Moreover, the couples have a shorter union duration, are younger, have fewer children and reside more often in the Paris region at the beginning of the union than the others.

The second profile (cluster 2, 30.7\%) comprises sole male earner couples' activity spaces, with two places located in distinct communes. It has the most heterogeneous trajectory pattern (measured by a maximum entropy of 0.90 , see Table 10). This cluster also exhibits a shorter duration spent in the main situation (59\% of the union duration) as shown in Appendix A, the trajectories contain episodes in other situations, implying woman's inactivity. Unlike couples in the previous cluster, the couples here have a longer union duration, are older and have more children than the others. Added to that, they reside relatively frequently outside the Paris region at the beginning of the union and experience the highest average number of moves during their trajectory.

The third cluster $\left(\mathrm{n}^{\circ} 3\right)$ groups $12.5 \%$ of the trajectories, representing biactive couples where women work closer to home than their husbands. A large number of the men in this cluster retire before the time of the survey.

The last three clusters comprise respectively bi-active couples where both spouses work in their commune of residence $(6.9 \%)$, where spouses work in the same commune $(5 \%)$, and where men work in their commune of residence $(4.9 \%)$. These are the most homogeneous clusters.

Finally, when we rapidly examine some attributes of the different clusters (Appendix A), the most striking distinction emerges between cluster 2, comprising older couples where the man is the breadwinner, with a larger number of children and who migrated from abroad or the provinces to the Paris region during their union, and cluster 1 , comprising dual-earners in the Paris region, who have seldom moved, are younger and have fewer than two children on average. 


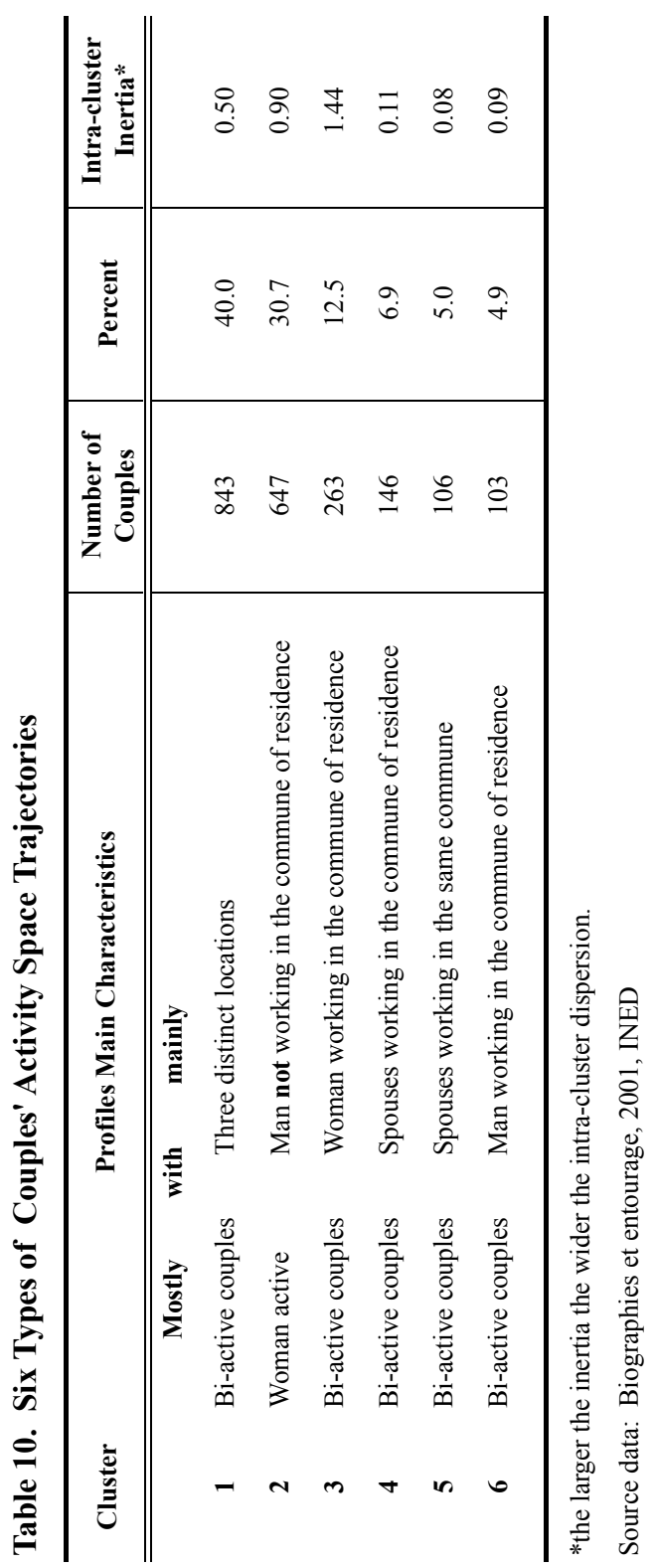


We can also look at the variations in cluster homogeneity over time. By calculating an entropy index, we can see that the clusters are more homogeneous in the middle of the couples' histories (see Appendix C). Situations are more diverse at the end of trajectories, mainly because of retirement and, above all, at the beginning of couples' histories, probably owing to the birth of children and to the necessary adaptation period when starting a relationship.

We've described the clusters by looking at indicators and graphs related to trajectories themselves or to couples' characteristics. But we may also wish to understand the determinants of the couples' membership of a specific cluster. This approach needs to focus on characteristics that were not acquired during the union and on fixed variables (such as sex or origin). So we performed a multinomial logistic model with the place of residence at the beginning of the union, the year of the entry into union (which is here equivalent to the union duration) and spouses' occupation at the beginning of the union as dependant variables (Appendix D). A clear opposition appears between cluster 1 and almost all the other clusters: residing in the Paris region at the beginning of the union, which itself dates back from the most recent period (1975-95) has a positive impact on the membership of cluster 1 , whereas the length of union effect is mostly positive for the other clusters. Concerning occupations, the main fact is that being self-employed leads to a higher proximity between the place of residence and the place of work. Finally, couples with men in high level occupations and inactive women seem more likely to belong to cluster 2 .

Most couples in their reproductive lives are faced with residential choices which are in part influenced by their family and occupational choices. Whether both couple members work outside their home, or only one of them, whether they have children or not, the territory defined by their place(s) of residence and place(s) of work results from an equation in terms of gender roles, distances, career strategy, etc. This life space perspective that elegantly formalizes the linked dynamics of two partners' common life course is a first step to giving empirical substance to the complex notion of interactive non-independent trajectories.

\section{Conclusion}

We have given here a detailed overview of different methodologies that can be used to describe and measure the territories to which individuals relate over time. Revisiting various types of territories identified in previous geographical, sociological or demographic studies has provided the opportunity to explore different measures and modeling strategies. Relying on data analysis techniques, we suggest indicators and ways to build relevant typologies which were then tested on the rich data collected by the Biographies et entourage survey.

CSP 2010, 37.1-2: 207-244 
The applications that we have developed empirically show the scope of this conceptual framework i.e. the life space perspective. Not only do we produce consistent indicators that can be used in the study of demographic processes, but the territorial configurations exhibited result from migration patterns and depend on people's activity and social relationships. As such, they give a synthetic insight into the complex interactions occurring over time between individuals and their social environment, and we have shown here how, for example, they are connected to the study of family networks and intergenerational relationships. Another strength of this approach is its capacity to address the study of non-independent linked life courses in a very original way. In fact, in the field of life course studies, demographers need to analyze interactive biographies which are notoriously difficult to model. The study of the couples' activity space over time proposed here fully illustrates the vast potential of the life space perspective.

\section{Acknowledgement}

Responsibility for any errors rests with the authors.

\section{End Notes}

1. France is administratively divided into 25 régions, 21 in metropolitan France and 4 overseas. Each region is divided into départements: France comprises 100 departments (of which 96 are In metropolitan France). Continental departments' median area is 5985 squared kilometres. The smallest administrative division is called the commune, which roughly corresponds to a county: France counts 36,677 communes in 2001. These administrative divisions have remained stable over the $20^{\text {th }}$ century.

2. 14 was the minimum legal age for working for the generations of Biographies et entourage.

3. Which can differ from the number of different places according to the geographical precision with which the places are located but we will not elaborate on this here when we could work with the municipality level of precision given in the data.

4. None of the respondents had experienced living apart.

CSP 2010, 37.1-2: 207-244 
5. Moreover, a previous work showed that OMA and QHA applied to the same data give relatively close typologies of trajectories: the main clusters group the same type of trajectories and only differ by slight differences in their size (Robette and Thibault 2008).

\section{References}

Abbott, A. 1995. "Sequence analysis : New methods for old ideas." Annual Review of Sociology 21: 93-113.

Abbott, A. and Hrycak, A. 1990. "Measuring resemblance in sequence data: An optimal matching analysis of musicians' careers." American Journal of Sociology 96: 144-185.

Adams, E. S. 1998. "Territory size and shape in fire ants: A model based on neighbourhood interactions." Ecology 79(4): 1125-1134.

Avenel, C. 2000. "Les jeunes hommes et le territoire dans un quartier de grands ensembles.” Lien Social et Politiques 43: 143-154.

Barbary, O. and L. M. Pinzon Sarmiento. 1998. "L'analyse harmonique qualitative et son application à la typologie des trajectoires individuelles." Mathématiques, Informatique et Sciences Humaines 144: 29-54.

Bengtson, V.L. and R.E.L. Roberts. 1999. "Intergenerational solidarity in aging families: An example of formal theory construction." Journal of Marriage and the Family 53(4): 856-870.

Billari, F. 2001. "Sequence analysis in demographic research." Canadian Studies in Population 28(2): 439-458.

Blair-Loy, M. 1999. "Career patterns of executive women in finance: an optimal matching analysis." The American Journal of Sociology 104(5): 13461397.

Bonvalet, C., Bringé, A. and N. Robette. 2009. "Les trajectoires géographiques des Franciliens depuis leur départ de chez les parents," in Actes $d u$ colloque Approches quantitatives et qualitatives des mobilités : quelles complémentarités? In press.

Bonvalet, C., Gotman, A. and Y. Grafmeyer. 2007. Family Kinship and Place in France. London: Southern Universities Press. 
A Life Space Perspective to Approach Individual Demographic Processes

Bonvalet, C. and É. Lelièvre. 1995. "Du concept de ménage à celui d'entourage: une redéfinition de l'espace familial." Sociologie et Sociétés 27(2): 177-190.

Bonvalet, C. and É. Lelièvre. 2007. "The local dynamics of parent-child relationships." Journal of Housing and the Built Environment 22(3): 263-285.

Bonvalet, C. and É. Lelièvre. 2008. "Entourage: a web of relationships in reference spaces," in Beyond the Nuclear Family: Families in a Configurational Perspectives. E. Widmer and R. Jallinoja (eds.), Bern: PeterLang. Pp. 375-396.

Bonvalet, C. and J. Ogg. 2007. Measuring family support in Europe. London: Southern Universities Press.

Brooker, M. and I. Rowley. 1995. "The significance of territory size and quality in the mating strategy of the splendid Fairy-Wren." The Journal of Animal Ecology 64(5): 614-627.

Brown, L. A., Horton, F. E. and R. I. Wittick. 1970. "On place utility and the normative allocation of intra-urban migrants." Demography 7(2): 175-183.

Camstra, R. 1996. "Commuting and gender in a lifestyle perspective." Urban Studies 33(2): 283-300.

Chevalier, J. 1974. "Espace de vie ou espace vécu ? L'ambiguïté et les fondements du concept d'espace vécu." L'espace géographique 1: 68p.

Clark, W.A.V., Deurloo, M.C. and F. M. Dieleman. 2003. "Housing careers in the United States, 1968-93: Modelling the sequencing of housing states." Urban Studies 140(1): 143-160.

Clark, W.A.V. and M. Kuijpers-Linde. 1996. "Commuting in restructuring urban regions." Urban Studies 31(3): 465-483.

Collignon, B. 1996. Les Inuits: ce qu'ils savent du territoire. Paris, Montréal : l'Harmattan. 
Courgeau, D. 1975. "Le concept de migration," in Actes du 4ème colloque de démographie africaine. Paris: INED. Pp. 27-32.

Courgeau, D. 1985. "Interaction between spatial mobility, family and career lifecycle: A French survey." European Sociological Review 1(2): 139-162.

Courgeau, D. 1988. Méthodes de mesure de la mobilité spatiale: migrations internes, mobilité temporaire, navettes. Paris: INED.

Cribier, F. 1999. "Les migrations de retraite des Parisiens." Les Cahiers de l'IAURIF 122: 249-260.

Degenne, A., Lebeaux, M.O. and L. Mounier. 1995. "Construction d'une typologie de trajectoires à partir de l'enquête de suivi des jeunes des niveaux V, Vbis et VI," in : Deuxièmes journées CEREQ-LASMAS-IDL. CEREQ CNRS.

Deville, J. C. and G. Saporta. 1980. "Analyse harmonique qualitative," in Data analysis and informatics. E. Diday (ed.), Amsterdam: North Holland Publishing. Pp. 375-389.

Di Méo, G. 1996. Les territoires du quotidien. Paris: L'Harmattan.

Frémont, A. 1974. "Recherche sur l'espace vécu." L'espace géographique 3: $231-238$.

Genay, V. 1992. "Les déplacements domicile-travail. Recensement de la population de 1990." Insee Première 202: 4p.

Gordon, I. and R. Vickerman. 1982. "Opportunity, preference and constraint: An approach to the analyses of metropolitan migration." Urban Studies 19: $114-126$.

Gotman, A. 1999. "Géographies familiales, migrations et générations," in Family Kinship and Place in France. Translation 2007. Bonvalet C. et al. (eds.), London: Southern University Press, Pp. 69-134.

Halpin, B. and T. W. Chan. 1998. "Class careers as sequences: An optimal matching analysis of work-life histories." European Sociological Review 14(2): 111-130.

CSP 2010, 37.1-2: 207-244 
A Life Space Perspective to Approach Individual Demographic Processes

Hannes, E., Janssens, D. and G. Wets. 2009. "Does space matter? Travel mode scripts in daily activity travel." Environment and Behavior 41(1): 75100.

Hannes, E., Janssens, D. and G. Wets. 2008. "Destination choice in daily activity travel: Mental map's repertoire.” Journal of the Transportation Research Board (2054): 20-27.

Hooimeijer, P. and B. van der Knaap. 1994. "From flows of people to networks of behaviour." Nederlandie Geograflsche Studies 173: 177-185.

Hugo, G. J. 1982. "Circular migration in Indonesia.” Population and Developement Review 8(1): 59-83.

Kokoreff, M. 1994. "La Dimension spatiale des modes de vie des jeunes. Le cas d'une cité de la banlieue parisienne." Sociétés contemporaines 17: 29-49.

Lefebvre, H. 1991. The Production of Space. Oxford: Basil Blackwell.

Lelièvre, E., Bonvalet C. and X. Bry. 1998. "Event history analysis of groups. The findings of an on-going research project." Population 10(1): 11-37.

Lelièvre, E. and C. Imbert. 2002. "L'entourage des Franciliens de 50 à 70 ans s'étend au-delà des limites de la région," in Atlas des Franciliens. T3. Paris: INSEE IAURIF. Pp. 44-45.

Lelièvre, E and N. Robette. 2005. Les espaces de référence des individus : définir et mesurer les espaces de vie. Paper presented at IUSSP XXV International Population Conference, Tours, France, July 2005.

Lelièvre, E and G. Vivier. 2001. "Évaluation d'une collecte à la croisée du quantitatif et du qualitatif : l'enquête." Biographies et entourage. Population 6: 1043-1073.

Ley, D. 1983. A Social Geography of the City. New York: Harper \& Row.

Massot, M. H. 1998. "Espace de vie - espace de travail," in Pumain, D. and Mattei, M. F. (eds.), Données sociales. Sankt Augustin, Germany: Anthropos. Pp. 147-156.

Metton, A. 1974. "L'espace perçu: diversité des approches." L'espace géographique 3: 228-230.

CSP 2010, 37.1-2: 207-244 
Meurs, D., Pailhé, A. and P. Simon. 2006. "The persistence of intergenerational inequalities linked to immigration: Labour market outcomes for immigrants and their descendants in France." Population-E 61(5/6): 645-682.

Ní Bhrolcháin, M. and W. Sigle-Rushton. 2005. "Partner supply in Britain and the US: Estimates and gender contrasts." Population-E 60(1/2): 37-64.

Robette, N. and N. Thibaut. 2008. "Comparing qualitative harmonic analysis and optimal matching. An exploratory study of occupational trajectories." Population-E 63(4): 533-556.

Stovel K, and M. Bolan. 2004. "Residential trajectories: Using optimal alignment to reveal the structure of residential mobility." Sociological Methods \& Research 32(4): 559-598.

Stovel, K., Savage, M. and P. Bearman. 1996. "Ascription into achievement: models of career systems at Lloyds Bank, 1890-1970.” American Journal of Sociology 102(2): 358-399.

Tyre, A. J., Possingham, H. P. and D. B. Lindenmayer. 2001. "Inferring process from pattern: Can territory occupancy provide information about life history parameters?" Ecological Applications 11(6): 1722-1737.

Vilhelmson, B. 1999. "Daily mobility and use of time for different activities: The case of Sweden." GeoJournal 48(3): 177-185.

Warnes, A. M. 1993. "The development of retirement migration in Great Britain.” Espace, populations, sociétés 3: 451-464.

Wellman, B. 1999. Networks in the Global Village. Boulder: Westview Press.

Widmer, E. and R. Jallinoja. 2008. Beyond the Nuclear Family: Families in a Configurational Perspectives. Bern: Peter Lang. 
A Life Space Perspective to Approach Individual Demographic Processes

Appendix A. Cluster Description

\begin{tabular}{|c|c|c|c|c|c|c|c|c|c|}
\hline \multicolumn{3}{|c|}{ Cluster } & Total & 1 & 2 & 3 & 4 & 5 & 6 \\
\hline \multicolumn{3}{|c|}{$\mathbf{N}$} & 2109 & 843 & 647 & 263 & 146 & 106 & 103 \\
\hline \multicolumn{10}{|c|}{ Duration spent in (proportion) } \\
\hline A & 1 location & - & 0.03 & 0.01 & 0.07 & 0.01 & 0.01 & 0.01 & 0.01 \\
\hline $\mathrm{B}$ & 2 locations & $\mathrm{R}=\mathrm{Mw}$ & 0.07 & 0.01 & 0.18 & 0.02 & 0.07 & 0.02 & 0.04 \\
\hline $\mathrm{C}$ & 2 locations & $\mathrm{R}^{1} \mathrm{Mw}$ & 0.24 & 0.08 & 0.59 & 0.11 & 0.04 & 0.10 & 0.02 \\
\hline $\mathrm{D}$ & 2 locations & $\mathrm{R}=\mathrm{Ww}$ & 0.02 & 0.00 & 0.01 & 0.08 & 0.04 & 0.00 & 0.01 \\
\hline $\mathrm{E}$ & 2 locations & $\mathrm{R}^{1} \mathrm{WW}$ & 0.04 & 0.07 & 0.01 & 0.02 & 0.02 & 0.03 & 0.03 \\
\hline $\mathrm{F}$ & 3 locations & $\mathrm{R}=\mathrm{Mw}=\mathrm{Ww}$ & 0.06 & 0.01 & 0.02 & 0.03 & 0.66 & 0.05 & 0.04 \\
\hline G & 3 locations & $\mathrm{R}=\mathrm{Mw}$ & 0.05 & 0.02 & 0.01 & 0.01 & 0.04 & 0.01 & 0.62 \\
\hline $\mathrm{H}$ & 3 locations & $\mathrm{R}=\mathrm{Ww}$ & 0.10 & 0.03 & 0.03 & 0.60 & 0.05 & 0.01 & 0.02 \\
\hline I & 3 locations & $\mathrm{Mw}=\mathrm{Ww}$ & 0.05 & 0.02 & 0.01 & 0.01 & 0.03 & 0.64 & 0.01 \\
\hline $\mathrm{J}$ & 3 locations & all $^{1}$ & 0.35 & 0.74 & 0.08 & 0.12 & 0.05 & 0.10 & 0.16 \\
\hline \multicolumn{10}{|c|}{ At least one episode in state (proportion) } \\
\hline A & 1 location & - & 0.15 & 0.06 & 0.33 & 0.07 & 0.08 & 0.09 & 0.07 \\
\hline $\mathrm{B}$ & 2 locations & $\mathrm{R}=\mathrm{Mw}$ & 0.24 & 0.06 & 0.50 & 0.11 & 0.38 & 0.11 & 0.29 \\
\hline $\mathrm{C}$ & 2 locations & $\mathrm{R}^{1} \mathrm{Mw}$ & 0.57 & 0.42 & 0.93 & 0.54 & 0.23 & 0.47 & 0.17 \\
\hline $\mathrm{D}$ & 2 locations & $\mathrm{R}=\mathrm{Ww}$ & 0.09 & 0.03 & 0.06 & 0.31 & 0.23 & 0.04 & 0.04 \\
\hline $\mathrm{E}$ & 2 locations & $\mathrm{R}^{1} \mathrm{WW}$ & 0.21 & 0.33 & 0.11 & 0.13 & 0.13 & 0.25 & 0.22 \\
\hline $\mathrm{F}$ & 3 locations & $\mathrm{R}=\mathrm{Mw}=\mathrm{Ww}$ & 0.19 & 0.09 & 0.12 & 0.19 & 1.00 & 0.29 & 0.26 \\
\hline $\mathrm{G}$ & 3 locations & $\mathrm{R}=\mathrm{Mw}$ & 0.18 & 0.15 & 0.10 & 0.11 & 0.32 & 0.09 & 1.00 \\
\hline $\mathrm{H}$ & 3 locations & $\mathrm{R}=\mathrm{Ww}$ & 0.31 & 0.23 & 0.21 & 0.97 & 0.30 & 0.14 & 0.12 \\
\hline I & 3 locations & $\mathrm{Mw}=\mathrm{Ww}$ & 0.17 & 0.16 & 0.09 & 0.09 & 0.16 & 1.00 & 0.11 \\
\hline $\mathrm{J}$ & 3 locations & all $^{1}$ & 0.67 & 0.99 & 0.41 & 0.56 & 0.36 & 0.48 & 0.63 \\
\hline \multicolumn{10}{|c|}{ Number of episodes in state } \\
\hline A & 1 location & - & 0.17 & 0.06 & 0.39 & 0.08 & 0.08 & 0.09 & 0.09 \\
\hline $\mathrm{B}$ & 2 locations & $\mathrm{R}=\mathrm{Mw}$ & 0.30 & 0.06 & 0.65 & 0.13 & 0.43 & 0.13 & 0.36 \\
\hline $\mathrm{C}$ & 2 locations & $\mathrm{R}^{1} \mathrm{Mw}$ & 0.78 & 0.55 & 1.34 & 0.73 & 0.26 & 0.62 & 0.20 \\
\hline D & 2 locations & $\mathrm{R}=\mathrm{Ww}$ & 0.10 & 0.04 & 0.06 & 0.37 & 0.24 & 0.04 & 0.04 \\
\hline $\mathrm{E}$ & 2 locations & $\mathrm{R}^{1} \mathrm{WW}$ & 0.24 & 0.38 & 0.11 & 0.15 & 0.15 & 0.26 & 0.27 \\
\hline $\mathrm{F}$ & 3 locations & $\mathrm{R}=\mathrm{Mw}=\mathrm{Ww}$ & 0.24 & 0.11 & 0.15 & 0.22 & 1.33 & 0.32 & 0.32 \\
\hline G & 3 locations & $\mathrm{R}=\mathrm{Mw}$ & 0.21 & 0.17 & 0.11 & 0.12 & 0.38 & 0.09 & 1.32 \\
\hline $\mathrm{H}$ & 3 locations & $\mathrm{R}=\mathrm{Ww}$ & 0.40 & 0.27 & 0.25 & 1.36 & 0.39 & 0.15 & 0.15 \\
\hline I & 3 locations & $\mathrm{Mw}=\mathrm{Ww}$ & 0.19 & 0.17 & 0.09 & 0.10 & 0.18 & 1.21 & 0.11 \\
\hline $\mathrm{J}$ & 3 locations & all $^{1}$ & 0.93 & 1.41 & 0.53 & 0.79 & 0.41 & 0.64 & 0.82 \\
\hline \multicolumn{3}{|c|}{ Total number of episodes } & 3.55 & 3.23 & 3.68 & 4.04 & 3.86 & 3.57 & 3.67 \\
\hline \multicolumn{3}{|c|}{ Total number of transitions } & 2.55 & 2.23 & 2.68 & 3.04 & 2.86 & 2.57 & 2.67 \\
\hline \multicolumn{10}{|c|}{ Residence at the beginning of the union } \\
\hline \multicolumn{3}{|c|}{ Paris region } & 0.80 & 0.87 & 0.71 & 0.79 & 0.72 & 0.89 & 0.81 \\
\hline \multicolumn{3}{|c|}{ province } & 0.11 & 0.08 & 0.15 & 0.12 & 0.12 & 0.05 & 0.10 \\
\hline \multicolumn{3}{|c|}{ abroad } & 0.09 & 0.04 & 0.13 & 0.08 & 0.15 & 0.07 & 0.10 \\
\hline \multicolumn{3}{|c|}{ Total number of moves } & 1.74 & 1.53 & 2.21 & 1.64 & 1.33 & 1.50 & 1.54 \\
\hline \multicolumn{10}{|c|}{ proportion $>=60$ years old } \\
\hline \multicolumn{3}{|l|}{ men } & 0.46 & 0.40 & 0.55 & 0.44 & 0.47 & 0.45 & 0.36 \\
\hline \multicolumn{3}{|c|}{ women } & 0.33 & 0.27 & 0.40 & 0.33 & 0.34 & 0.36 & 0.29 \\
\hline \multicolumn{3}{|c|}{ Number of children } & 2.07 & 1.63 & 2.81 & 1.96 & 2.01 & 1.73 & 1.75 \\
\hline \multicolumn{3}{|c|}{ union duration } & 30.50 & 28.50 & 32.60 & 31.40 & 32.10 & 31.40 & 29.20 \\
\hline
\end{tabular}

CSP 2010, 37.1-2: 207-244 
Appendix B

Distribution of Activity Space Configurations by Period for each Cluster as described in Table 10

\section{Cluster 1}

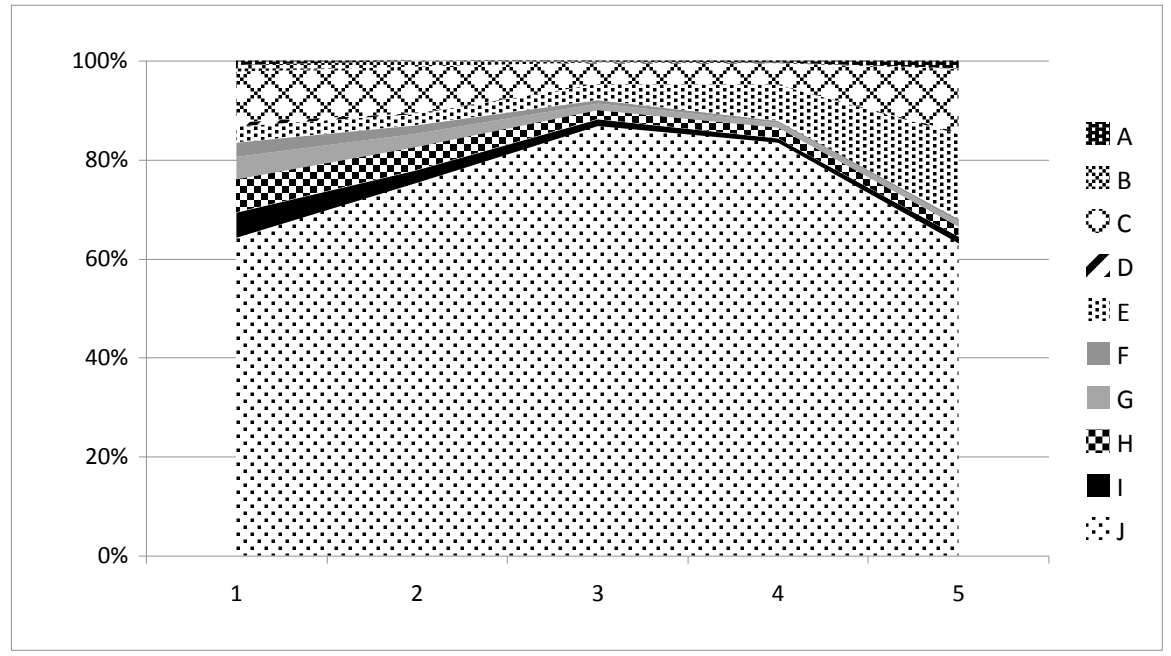

Cluster 2

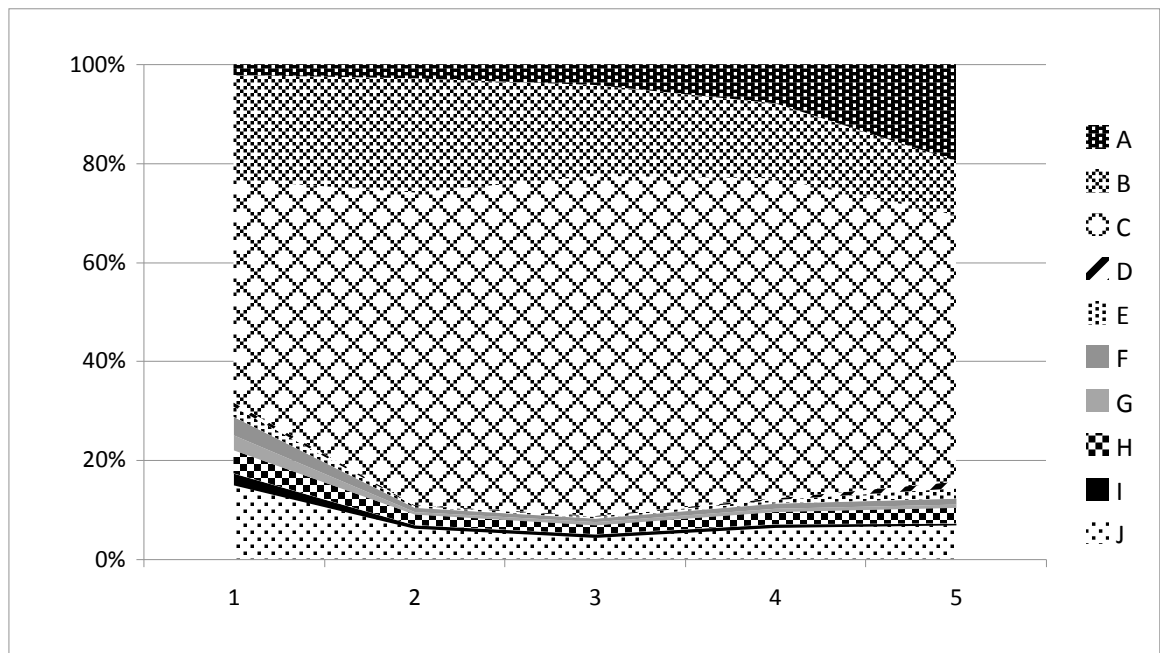

Configurations A to J refer to the dispersion and number of locations in the couples' activity spaces described in Table 9.

CSP 2010, 37.1-2: 207-244 
Appendix B (Continued)

Distribution of Activity Space Configurations by Period for each Cluster

as described in Table 10

Cluster 3

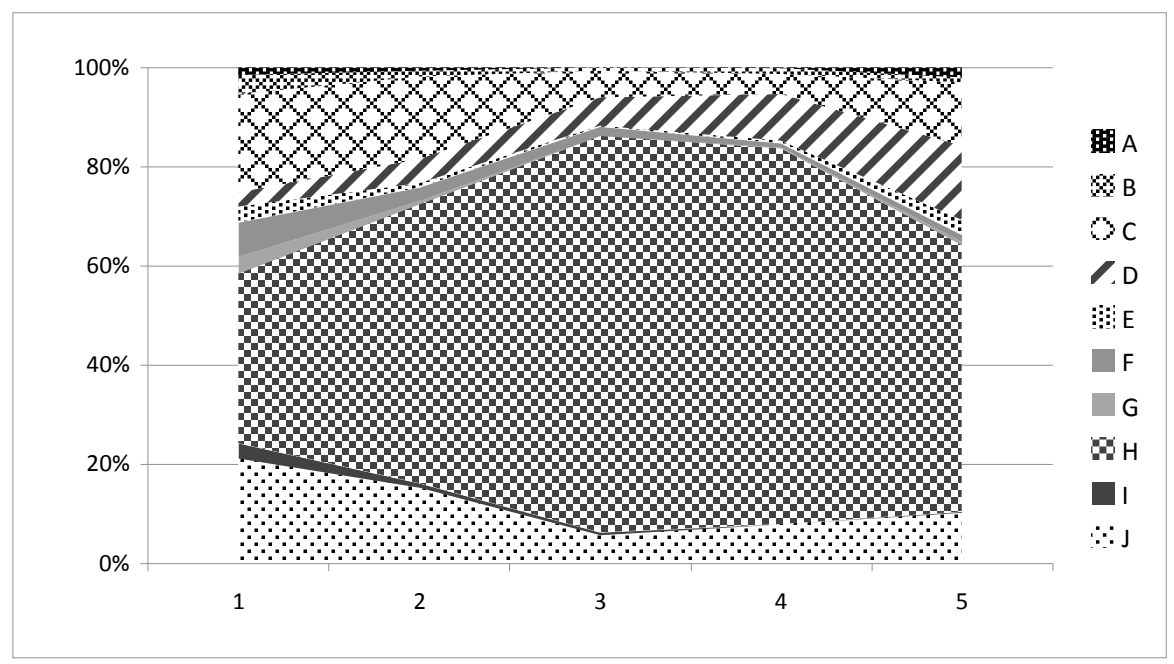

Cluster 4

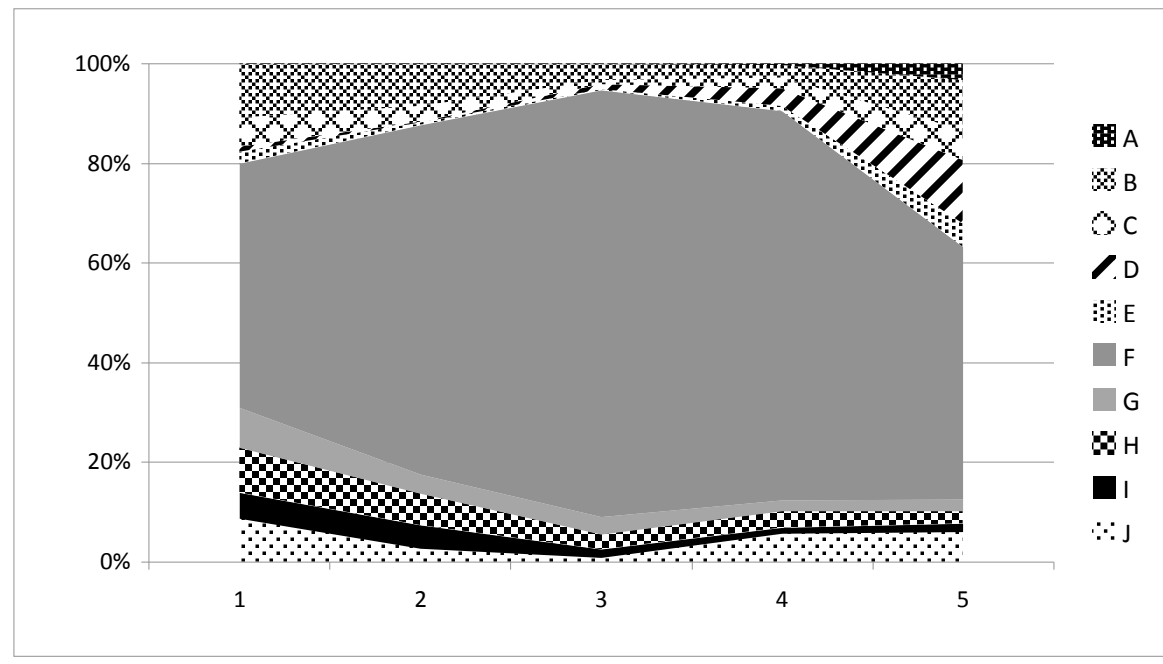

Configurations A to J refer to the dispersion and number of locations in the couples' activity spaces described in Table 9.

CSP 2010, 37.1-2: 207-244 
Appendix B (Continued)

Distribution of Activity Space Configurations by Period for each Cluster as described in Table 10

Cluster 5

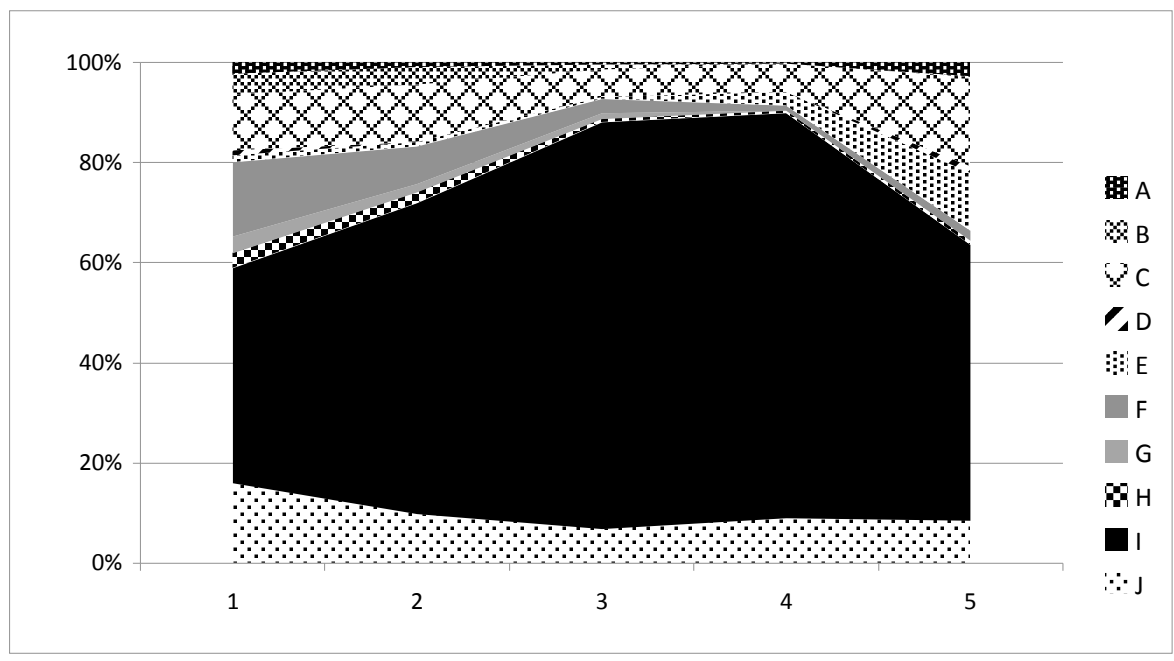

Cluster 6

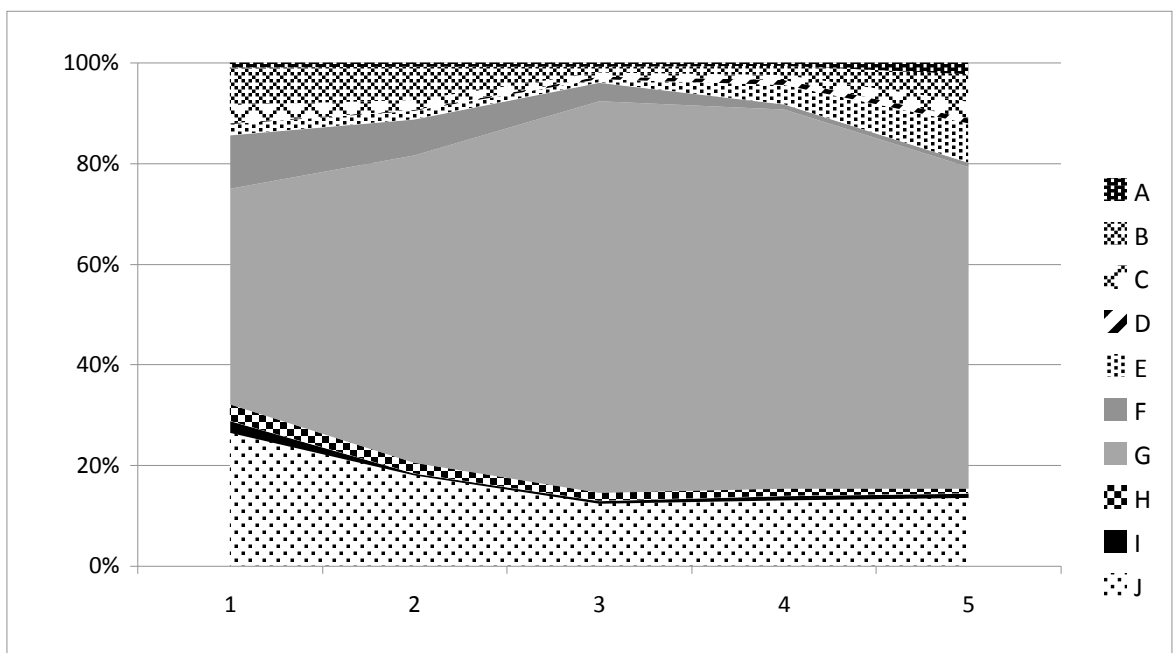

Configurations A to J refer to the dispersion and number of locations in the couples' activity spaces described in Table 9. 


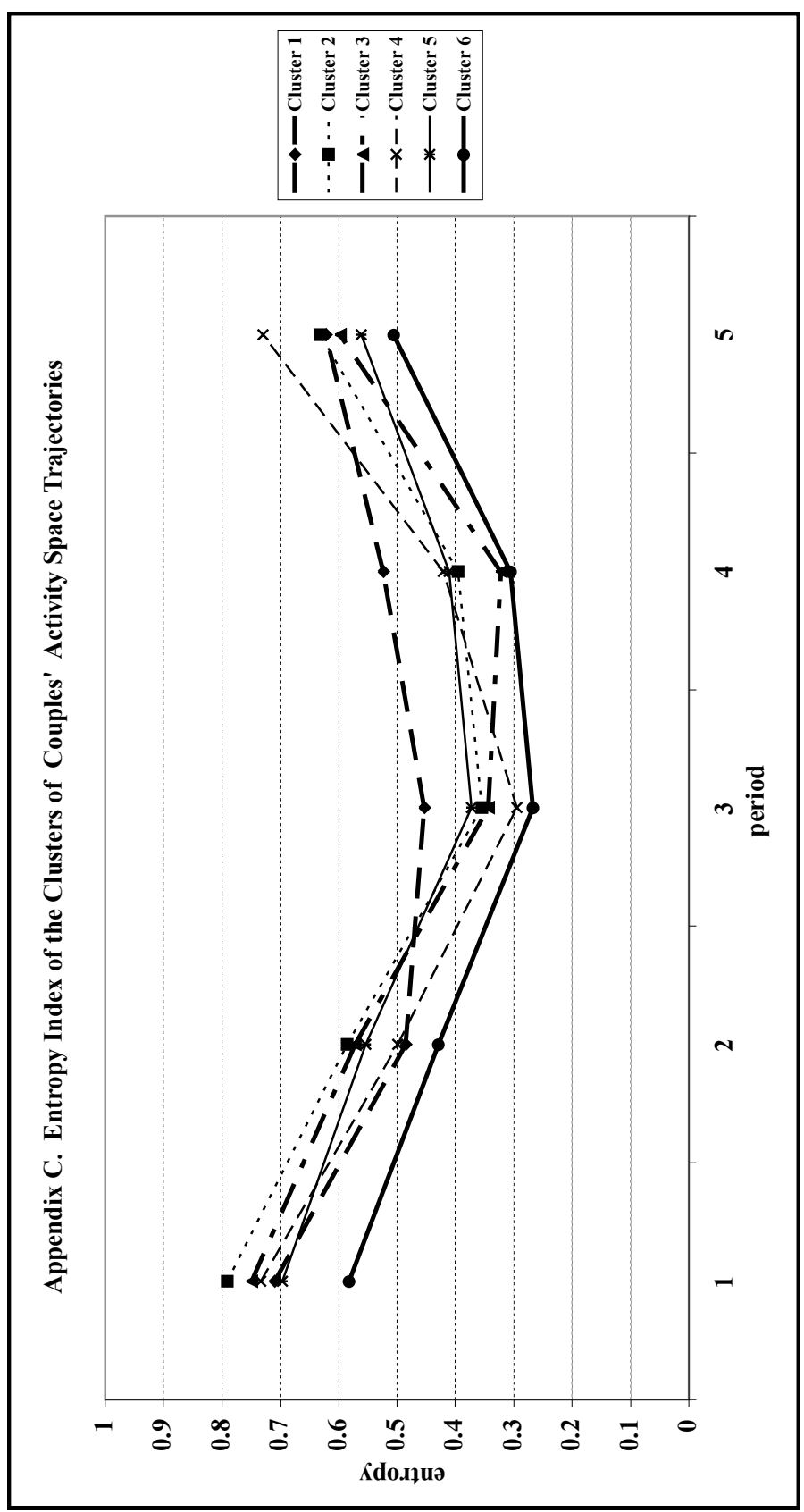

CSP 2010, 37.1-2: 207-244 


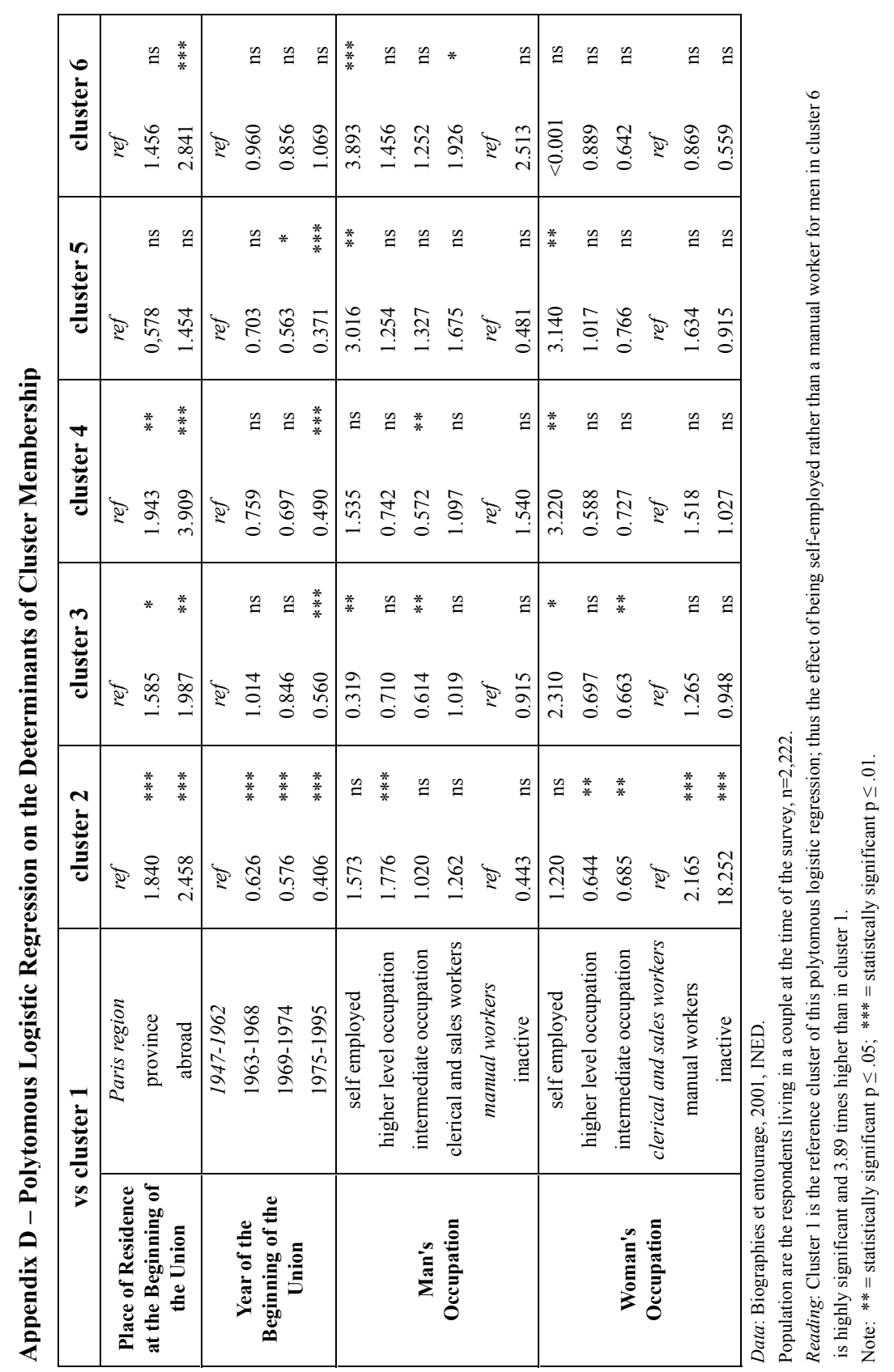

CSP 2010, 37.1-2: 207-244 